\title{
Exploitation of Rural Employment in the Perspective of Precise Poverty Alleviation
}

\author{
Ping Li \\ Harbin University of commerce, Harbin, Hei Longjiang Province \\ 752952314@qq.com
}

Keywords: Accurate poverty alleviation; Rely on the local; Employment development

\begin{abstract}
Accurate poverty alleviation has entered the tackling times, and every effort has been made to improve the ability of the poverty-stricken groups themselves, and improve the ability of the poor become the main idea of poverty alleviation work. In combination with the national "rain plan", this paper puts forward the development of local employment from the point of view of labor demand, based on the characteristics of the poor and considered the environmental dependence on land and rural life. Combined with principle of work development, it is pointed out that the development of local jobs should consider poverty-alleviating industrial policy, the resource endowment of poverty-stricken areas, the national policy, the local urbanization, and the beautiful rural construction.
\end{abstract}

\section{Introduction}

In 2013, National chairman Xi Jinping proposed the idea of "Accurate Poverty Alleviation". In 2014, the CPC Central Committee formally proposed the mechanism of "Accurate Poverty Reduction". In 2015, the CPC Central Committee will convene a working conference on poverty alleviation and development to make sure that the rural out of poverty. October 17, 2016 The State Council Information Office published the White Paper on Poverty Reduction and Human Rights Progress in China. It can be seen, the state gradually deepen and promote accurate poverty alleviation work. As of the end of 2015, there are 14 concentrated contiguous special difficult areas, 832 impoverished counties, 128,000 poor village, and impoverished population of 55750000 people in China. To get the 2020 target, from 2016, we should make more than 10 million people annual out of poverty. China's poverty alleviation task remains arduous.

Poverty is a major obstacle and difficulty in building a Chinese dream and building a harmonious society. Therefore, eliminating poverty is the prerequisite and foundation of building a harmonious society in the new rural construction. To "effectively safeguard the vital interests of poor and vulnerable groups so that they can share the benefits and achievements of reform and opening up, so as to promote economic, social and human development, accelerate the socialist modernization" as a guide, in order to achieve a moderately prosperous society, Change the way of poverty alleviation from the "flood irrigation" to "precision drip", the state proposed accurate poverty alleviation strategy.

\section{The Poor Families ' Income}

The Composition of Peasants' Income. First, household operating income is now the main source of income of farmers. For thousands of years, the natural relationship between land and farmers is closed, so that farmers have a special feeling of land. After reform, the implementation of household contract responsibility system improved the enthusiasm of the peasant. Farmers' income continues to grow now. The income of the family also includes the operating income from the forestry, poultry, livestock and other aquaculture industries. In addition, the income from farming is the most important part of the household income.

Second, the wage income becomes the second source of farmers' income. With the improvement of agricultural efficiency, most of the labor force is liberated from the land, and the labor income of migrant workers and temporary short-term workers become the second source of farmers' income. 
However, due to the different nature of the work unit, the wage difference is relatively large. It is also lead large differences in rural incomes.

Third, the transfer of income becomes the third source of farmers' income. Government transfer income, including food subsidies, agricultural subsidies, medical insurance and temporary relief. Non-government transfer income mainly refers to red and white wedding entertainment income, non-family members of the funding, inheritance, and other aspects of the transfer of income. China's rural red and white wedding event income has become the main source of transfer income.

Fourth, the property income refers to the automobile, agricultural machinery and other means of production income, housing rental income.

Fifth, investment income mainly refers to the purchase of stocks, funds, bonds, financial products, in rural households in the proportion of such income the smallest, many families without such income at all.

The Composition of Poor Households' Income. The income structure of the poor households is characterized by the following aspects. Firstly, the income of the poor households mainly depends on the income from the family business, which mainly refers to the agricultural income, strongly dependent on land and other resources. Second, the low wage income, poor families lack of labor or lack of skilled labor, no long-term stability of the work, from the object of accurate poverty alleviation, the majority of poor families have the ability to work, but lack of demand for rural labor positions. The third transfer of income is very low, cannot become the main rely on life. Fourth, the property and investment income is almost zero.

Therefore, under the view of precise poverty alleviation, taking the economic growth as the guiding law, from the microscopic point of view, it is necessary to improve the income of poor families as the main explicit target. Raising the labor income of poor families is an important measure for poverty alleviation. It is also one of the ways to raise the income level of poor families and get rid of long-term poverty. Precise pro-poor "rain plan" for poor family members, especially the "two epigenetic" and other young and middle-aged labor force for vocational skills training, and achieved good results, providing a high quality labor force, from the perspective of labor supply and to solve the problem of poor capacity of poor groups. The next step, need to think from the perspective of labor demand, the development of labor positions for the poor groups, build a platform for rural labor market, so that the law of the market in precise poverty alleviation play its due role. To avoid the "rain plan" training skills to become the skill of dragon kills, taking into account the rural poor families of land, local culture, village organizations, we should develop rely on the local employment. Therefore, this article from the perspective of accurate poverty alleviation, taking into account the factors of labor market demand, we take rely on rural areas of employment development as the main research object.

\section{Rely on the Local Employment Research}

Rely on the local employment, not leaving the local business, not leaving the local pension, not separated from the urbanization of urban life have become the focus of social concern, but also became a hot research topic. "On the Construction of Small Towns", a book, Mr. Fei takes Jiang Village and $\mathrm{Yu}$ Village in the survey to build small towns, he said: "The rural labor force is a necessary link between urban and rural development." The number of rural labor force in China has been increasing, but the growth rate has continued to decline, and with the regional economic development gap is gradually narrowing, more and more rural migrant workers from the city back to rural areas. It is a phenomenon prevalent in Chinese peasants nowadays. It refers to the young people who leave their hometowns to live in the nearby towns, but they are not completely separated from their homeland. They travel between town and countryside seasonally.

Principles Of Rely On the Local Job Design. The design of rely on the local job is not only to improve the wage income of farmers as the goal, but also good for the whole society. Taking skills and needs of farmers into account, through the development of local industries, beautiful homes and urbanization development needs of local farmers qualified for job content, permissions and work relations and other aspects of the design and integration process need us also pay attention to. In 
view of the production and living conditions of rural farmers and their dependence on land and home, the development of rely on the local job should follow the following principles:

Principle of Setting up Jobs. Organizational goals determine the task, the job set to the needs of the work tasks as the prerequisite, which is due to the principle of setting up posts. In the implementation of accurate poverty alleviation strategy, according to the specific nature of poverty alleviation industry and enterprise development needs, cannot be set without job tasks. Position and people should be set up and configuration of the relationship cannot be reversed, confuse the causal relationship. Organize work according to organizational goals, and set up jobs based on work.

Principle of Static and Dynamic. With the development of accurate poverty alleviation and rural urbanization, the "rely on local job" design should also be dynamic. For basic jobs, suitable for static-oriented work; and rural cooperatives are closely related to the business position, will have to use dynamic analysis and design.

Principle of Full Load Work. Full-load work is to make the staff to achieve the best working condition, to make sure people to do their best to make the best use of its best effect. In the organization, the workload of each job should be full, to ensure the effective use of time to work, which is to improve the job design of a basic task. If the job is low load, will inevitably lead to accurate poverty-stricken people, financial and material waste, is not conducive to cost reduction; if overloaded, although can bring temporary high efficiency, but will over cost labor psychological participants impact, but also to bring unnecessary damage to the device.

Principle of Capacity Development. The development of staff capacity not only by training, exercise in practice is also a necessary way. Especially in the perspective of accurate poverty alleviation, the capacity development of poverty-stricken peasants can be improved through the work setting in addition to the training of the national "rainstorm plan", so as to maximize the ability of the peasants in employment.

\section{Specific Measures for Relying on Local Jobs}

To develop and design industry manufacturing positions according to different areas of industrial poverty alleviation planning. For example, through the transfer of labor-intensive industries such as textiles, garment processing, food processing and other positions, different industries can be derived from different positions, these job are not demanding so much skills, so, the basic skills can be get from precise poverty alleviation of the "rain plan". The training object improves the employment rate of, increase their employment income, and change the situation of poverty.

To develop new service industry positions. For the poor families, especially the "two epigenetic", could use the national's innovation and entrepreneurship policy, the development of service-oriented positions, to encourage them to go to work, even with the help of poverty alleviation policies and funds to start their own businesses, drive more people employment. Such as beauty, hairdressing, catering, electricity and other industries, requires a large number of decentralized labor force, these positions flexibility, have higher income, these positions can mobilize the vitality of rural economic development has become the main driving force of rural urbanization.

To develop ecological green planting and breeding positions by consider of regional resource endowments, Green ecological industry cultivation, breeding jobs suitable for farmers, they can upgrade skills easily, consider the different regional resource endowment, it can create a large number of jobs in the government poverty alleviation policy.

To develop infrastructure construction posts as the combination of local urbanization. In the process of infrastructure construction, a large number of manual laborers are needed, while the return of rural surplus labor force provides a great deal of suitable labor force, which is of great significance to the poverty-stricken areas, such as the poverty-stricken areas. It also created a lot of jobs.

To develop rural image maintenance and other public welfare positions take consider of combination of beautiful rural construction. The government funded the purchase of public welfare positions. According to demand factor, both taking into account the actual needs of the work of the 
village, but also taking into account the establishment of poor family registers. In accordance with the principle of giving priority to resettling zero-employment families, especially hard-working families and workers with large working age, it has focused on the development of care for the elderly and left-behind children, care of the disabled, social security, rural road maintenance, labor security and other public welfare posts, to take part-time employment system.

\section{Conclusions}

Poverty has brought great challenge to the survival of human society for a long time. The accurate strategy of poverty alleviation is not only beneficial to building a well-off society in China, but also making a great contribution to the world's battle to poverty. In view of the dependence of the farmers in the poor areas on the means of production and their homes, mobilizing the potential of poverty-stricken areas is not only an effective measure to solve the poverty-stricken areas, but also an important measure to build beautiful homes and develop local urbanization. Based on the precious poverty alleviation industries and regional resource endowments, the development of local jobs is conducive to improving the labor income of poor groups, improve their ability to self-reliance, and help them get out of poverty forever.

\section{Acknowledgements}

Heilongjiang Province, Department of Humanities and Social Sciences Project (2016) : Precision Poverty Alleviation Strategy of Poverty-Stricken Areas in Suihua City;

Heilongjiang Province Economic and Social Annual Key Issues (2016): The Development of Rural Cooperatives in the Main Grain Producing Areas in Heilongjiang Province

\section{References}

[1] X.T. Fei, On the Construction of Small Towns(Group Words Publishing House, China 2000), p.310

[2] M.Y Wang, Research on China's Urbanization in the Process of Leaving the Land does not Leave the Home (Ph.D., Heilongjiang University,China2015), p.19

[3] H.Sun, HAINAN TODAY,(2013) No.4, p.39

[4] Z.Z. Guan, The Return of Rural Labor Force Employment Problem(Ph.D., Nanjing University,China2015), p.36

[5] Z.L.Shi , Y.Y.Yang, Social Science Research, (2012) No.4, p.158

[6] X.L.Yang and L.X, Shanhang Qingdao Branch Production Command Center post design improvement (Ph.D., Shandong University,China2015), p.21

[7] Z.W.Wang, China Population, Resources and Environment,(2013) No.1, p. 132

[8] X.Q.Xie and S.S.Lv, China soft science,(2015) No.12, p. 63

[9] Y.Y. Li, Henan Agriculture,(2016) No.1, p. 20

[10]M.N. Guo, The commercial economy,(2016) No.3, p. 76

[11]A.P. Xu, Financial Times,(2016) No.4, p. 34 